Cite this: J. Mater. Chem. A, 2014, 2 , 7988

Received 6th February 2014 Accepted 5th April 2014

DOI: $10.1039 / c 4 t a 00637 b$

www.rsc.org/MaterialsA

\section{Effects of cationic substitution on structural defects in layered cathode materials $\mathrm{LiNiO}_{2}$}

\begin{abstract}
Hungru Chen, ${ }^{*}$ James A. Dawson and John H. Harding
The electrochemical properties of layered rock salt cathode materials are strongly influenced by defects. The three most common defects in $\mathrm{LiNiO}_{2}$-based compounds, namely extra $\mathrm{Ni}$, $\mathrm{Li}-\mathrm{Ni}$ anti-site and oxygen vacancy defects have been investigated. The calculated defect formation energies are very low in $\mathrm{LiNiO}_{2}$, consistent with the difficulty in synthesizing stoichiometric defect-free $\mathrm{LiNiO}_{2}$. A systematic study is conducted to examine the effect of $\mathrm{Co}, \mathrm{Mn}$ and $\mathrm{Al}$ substitution on defect formation. It is shown that the presence of $\mathrm{Ni}^{2+}$ in the Li layer can be rationalized using ideas of superexchange interactions. In addition, a correlation between oxygen vacancy formation energy and oxygen charge is noted. This explains the better thermal stability obtained by early transition metal or Al substitutions.
\end{abstract}

\section{Introduction}

Layered rock salt structure materials with the general formula $\mathrm{LiMO}_{2}$ (where $\mathrm{M}$ is a transition metal) have been studied intensively due to their applicability as cathode materials in lithium ion batteries. $\mathrm{LiCoO}_{2}$ is the prototype commercially used cathode. However, cobalt is toxic and expensive and therefore the search for replacements for cobalt-based cathodes has lasted for decades. $\mathrm{LiNiO}_{2}$ is one of the potential cathode materials for lithium ion batteries. Although this compound has been studied for many years, the electronic, magnetic and local structures are still highly controversial.1,2

Experimentally it is not yet possible to synthesize perfect, stoichiometric $\mathrm{LiNiO}_{2}$. A certain fraction of extra nickel ions occupy the lithium sites making the true formula of the material $\left[\mathrm{Li}_{1-x} \mathrm{Ni}_{x}\right] \mathrm{NiO}_{2}$ (ref. 3) (this is referred to hereafter as extra $\mathrm{Ni}$ defects on the $\mathrm{Li}$ site). A recent theoretical study on $\mathrm{LiNiO}_{2}$ also predicts an unavoidable high concentration of Ni present in the Li layers at high temperature. ${ }^{4}$ Besides, $11 \%$ of $\mathrm{Li}-\mathrm{Ni}$ interlayer mixing (cation exchange between $\mathrm{Li}$ and $\mathrm{Ni}$ in the expected layered structure) is reported to occur in the $\mathrm{LiNiO}_{2}$-based material $\mathrm{LiNi}_{1 / 2} \mathrm{Mn}_{1 / 2} \mathrm{O}_{2}$ and $6 \%$ in $\mathrm{LiNi}_{1 / 3} \mathrm{Mn}_{1 / 3} \mathrm{Co}_{1 / 3} \mathrm{O}_{2} \cdot{ }^{5,6}$ The presence of $\mathrm{Ni}$ in the $\mathrm{Li}$ layers has a detrimental effect on the electrochemical performance of the material as a cathode. First, it disrupts the lithium diffusion by blocking the diffusion pathways. ${ }^{7}$ Second, it has been suggested that the presence of nickel in the lithium layer is responsible for first-cycle irreversibility.$^{8-10}$ During the first charge, the $\mathrm{Ni}^{2+}$ ions at Li sites are oxidized to smaller $\mathrm{Ni}^{3+}$ ions. This causes a local shrinkage around those nickel ions and therefore it is difficult to insert lithium ions back into the positions around them.

Department of Materials Science and Engineering, University of Sheffield, S1 3JD, UK. E-mail: chen.hungru@nims.go.jp
Oxygen loss is another issue in layered cathode materials. A recent study on $\mathrm{LiNi}_{0.8} \mathrm{Mn}_{0.1} \mathrm{Co}_{0.1} \mathrm{O}_{2-\delta}$ demonstrated that up to $\sim 12 \%$ oxygen loss occurs depending on the synthesis conditions and that there is a strong correlation between oxygen content and electrochemical performance. ${ }^{\mathbf{1 1}}$ Delithiated $\mathrm{Li}_{1-x} \mathrm{NiO}_{2}$ is not thermally stable. It undergoes a phase transition accompanied by oxygen evolution. It has been shown that the extent of oxygen evolution increases as $x$ increases. ${ }^{12}$ This irreversible structural change is concomitant with oxygen loss and maybe responsible for the observed capacity fading. ${ }^{\mathbf{1 3}, \mathbf{1 4}}$

In order to improve the electrochemical performance of $\mathrm{LiNiO}_{2}$, the strategy of partial substitution of $\mathrm{Ni}$ by other metal cations has been deployed. It is known that Co substitution gives better 2-D layered character. For $\mathrm{LiNi}_{1-x} \mathrm{Co}_{x} \mathrm{O}_{2}$ with $x>0.3$, nickel is no longer present in the lithium layer. ${ }^{15}$ As a result, the irreversibility seen at the first-cycle mentioned above disappears. By contrast, the interlayer mixing increases with Mn doping. ${ }^{\mathbf{1 6}}$ Nevertheless, $\mathrm{Li}_{x} \mathrm{Ni}_{0.5} \mathrm{Mn}_{0.5} \mathrm{O}_{2}$ exhibits excellent structural stability against oxygen loss ${ }^{17}$ at low Li content and therefore better safety. Al doping improves the thermal stability although $\mathrm{Ni}$ is still found in the $\mathrm{Li}$ layer. ${ }^{18,19}$ Cycling tests show that $10 \% \mathrm{Al}$ suppresses all the phase transitions observed for the $\mathrm{Li}_{x} \mathrm{NiO}_{2}$ system. ${ }^{19}$

Although the properties produced by partial cationic substitution are well studied, the reasons why these foreign dopants produce them are not clear. In this study, first-principles calculations are performed to investigate the structural defects of $\mathrm{Li}-\mathrm{Ni}$ anti-site, extra $\mathrm{Ni}$ and oxygen vacancy in $\mathrm{LiNiO}_{2}$ and the effect of $\mathrm{Ni}$ substitution by $\mathrm{Co}\left(\mathrm{LiNi}_{0.5} \mathrm{Co}_{0.5} \mathrm{O}_{2}\right), \mathrm{Al}\left(\mathrm{LiNi}_{0.5} \mathrm{Al}_{0.5} \mathrm{O}_{2}\right)$ and $\mathrm{Mn}\left(\mathrm{LiNi}_{0.5} \mathrm{Mn}_{0.5} \mathrm{O}_{2}\right)$. The same structural defects in $\mathrm{NaNiO}_{2}$ and $\mathrm{LiCoO}_{2}$ are also calculated for comparison.

\section{Defect formation energies}

In this study, we consider the presence of extra $\mathrm{Ni}$ in the $\mathrm{Li}$ layers, the Li-Ni interlayer mixing and the oxygen loss as point 
defects in the supposedly perfect layered $\mathrm{LiMO}_{2}$. The extra $\mathrm{Ni}$ defect can be considered as occurring through the following defect reaction

$$
" \mathrm{LiMO}_{2} "+2 \mathrm{NiO} \rightarrow 2 \mathrm{Ni}_{\mathrm{Li}}+2 \mathrm{M}_{\mathrm{M}}^{\prime}+\mathrm{Li}_{2} \mathrm{O}+\frac{1}{2} \mathrm{O}_{2}
$$

Similarly the interlayer mixing defect occurs through the reaction

$$
" \mathrm{LiMO}_{2} " \rightarrow \mathrm{Ni}_{\mathrm{Li}}^{\cdot}+\mathrm{M}_{\mathrm{M}}^{\prime}
$$

and the oxygen vacancy defect occurs through the reaction.

$$
" \mathrm{LiMO}_{2} " \rightarrow \mathrm{V}_{\mathrm{O}}+2 \mathrm{M}_{\mathrm{M}}^{\prime}+\frac{1}{2} \mathrm{O}_{2}
$$

In this work we define defect formation energies as the formation enthalpies of the above defect reactions at $0 \mathrm{~K}$. Two assumptions are made here. First, in solid phases the volume term can be neglected and therefore the enthalpy corresponds to the internal energy. Second, defects are assumed to distribute evenly in the crystal. In the case of extra Ni defects in $\mathrm{LiNiO}_{2}$, the defect formation energy per defect is then given as

$$
\begin{aligned}
\operatorname{DFE}(\text { extra Ni })= & \Delta G \\
= & \Delta H-T \Delta S \approx-E(\text { perfect })-E(\mathrm{NiO}) \\
& +E(\text { defective })+\frac{1}{2} E\left(\mathrm{Li}_{2} \mathrm{O}\right)+\frac{1}{4} E\left(\mathrm{O}_{2}\right)
\end{aligned}
$$

where $E$ (perfect) is the lattice energy of a perfect $\mathrm{LiNiO}_{2}$ cell and $E$ (defective) is the lattice energy of the cell containing one extra Ni defect.

Similarly the defect formation energy of interlayer mixing is

$$
E(\text { interlayer mixing })=-E(\text { perfect })+E(\text { defective })
$$

where $E$ (perfect) is the lattice energy of the perfect cell and $E$ (defective) is the lattice energy of the cell containing one interlayer mixing defect.

The defect formation energy of oxygen vacancy is

$$
E(\text { oxygen vacancy })=-E(\text { perfect })+E(\text { defective })+\frac{1}{2} E\left(\mathrm{O}_{2}\right)
$$

where $E$ (perfect) is the lattice energy of the perfect cell and $E$ (defective) is the lattice energy of the cell containing one oxygen vacancy.

For $\mathrm{LiNiO}_{2}$, the concentrations of $\mathrm{Ni}$ present in the Li layers and oxygen vacancies are reported to be a few percent and are far beyond the dilute limit. However by an appropriate choice of the supercell size, the correct defect concentration can be simulated by substitution of the appropriate number of defects in the cell.

\section{Computational approach}

In this study, first-principles calculations are performed to investigate the structural defects of interlayer mixing, extra $\mathrm{Ni}$ and oxygen vacancy in layered $\mathrm{LiNiO}_{2}$ and the effect of $\mathrm{Ni}$ substitution by $\mathrm{Co}\left(\mathrm{LiNi}_{0.5} \mathrm{Co}_{0.5} \mathrm{O}_{2}\right)$, $\mathrm{Al}\left(\mathrm{LiNi}_{0.5} \mathrm{Al}_{0.5} \mathrm{O}_{2}\right)$ and $\mathrm{Mn}$
$\left(\mathrm{LiNi}_{0.5} \mathrm{Mn}_{0.5} \mathrm{O}_{2}\right)$. The structural defects in layered $\mathrm{NaNiO}_{2}$ and $\mathrm{LiCoO}_{2}$ are also calculated for comparison.

All calculations are based on Density Functional Theory (DFT) in combination with the projector augmented wave (PAW) method. ${ }^{20}$ The generalized gradient approximation (GGA) is used with the Perdew-Burke-Ernzerhof functional ${ }^{21}$ and a Hubbard model $U$ correction ${ }^{22}$ is incorporated for the d electrons to give a better description of this strongly correlated system. The U parameters used for $\mathrm{Ni}$, Co and $\mathrm{Mn}$ are 6.5, 4.9 and $4.5 \mathrm{eV}$, respectively. These parameters are adapted from a self-consistent calculation. ${ }^{23}$ The plane wave energy-cutoff is set to $500 \mathrm{eV}$. For all cells, the $k$-point spacing is less than $0.05 \AA^{-1}$ in the Brillouin zone. Structural optimizations were performed until the residual force acting on each ion was less than $0.01 \mathrm{eV} \mathrm{A}^{-1}$. All calculations were carried out using the Vienna ab initio simulation package (VASP). ${ }^{24}$

For the calculation of perfect layered $\mathrm{LiNiO}_{2}$, a possible ground state cell with space group symmetry $P 2_{1} / c$ is used as the starting structure. ${ }^{2}$ In this $P 2_{1} / c$ cell the Jahn-Teller distortions of $\mathrm{Ni}^{3+}$ in the $\mathrm{NiO}_{2}$ slab are in a zigzag ordering. For calculations of layered $\mathrm{LiNi}_{0.5} \mathrm{Co}_{0.5} \mathrm{O}_{2}, \mathrm{LiNi}_{0.5} \mathrm{Al}_{0.5} \mathrm{O}_{2}$ and $\mathrm{LiNi}_{0.5} \mathrm{Mn}_{0.5} \mathrm{O}_{2}$ the two simplest in-plane cation orderings, linear and zigzag orderings, are considered as shown in Fig. 1. Supercells with 32 formula units containing 128 atoms are used in all defect calculations. The interlayer mixing defects and extra Ni defects in such a supercell correspond to a concentration of $3.125 \%$, which is well within the experimentally reported range of defect concentration in $\mathrm{LiNiO}_{2}$. Therefore the size of the cell is adequate for simulating the observed defects in $\mathrm{LiNiO}_{2}$ and there is no need for extrapolation to the infinite limit.

The interlayer mixing defect in layered $\mathrm{AMO}_{2}(\mathrm{~A}=\mathrm{Li}, \mathrm{Na})$ is constructed by swapping one $\mathrm{Ni}$ (Co in the $\mathrm{LiCoO}_{2}$ case) in the $\mathrm{MO}_{2}$ slab with the nearest A ion. The extra Ni defect is constructed by replacing one $\mathrm{A}$ ion by $\mathrm{Ni}$ in the supercell. The oxygen vacancy defect is constructed by removing one oxygen atom from the supercell.

\section{Results and discussion}

\section{Properties of undoped compounds}

Before proceeding to the defect structure calculations, the crystal and electronic structures of perfect $\mathrm{LiNi}_{0.5} \mathrm{Co}_{0.5} \mathrm{O}_{2}$, $\mathrm{LiNi}_{0.5} \mathrm{Al}_{0.5} \mathrm{O}_{2}$ and $\mathrm{LiNi}_{0.5} \mathrm{Mn}_{0.5} \mathrm{O}_{2}$ are first determined. In (a)

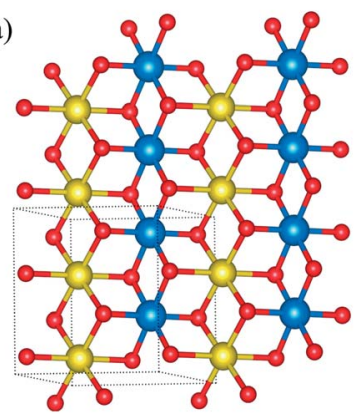

(b)

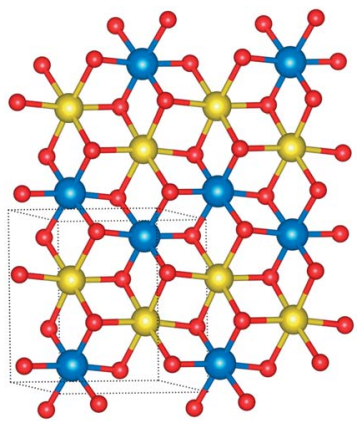

Fig. 1 (a) Linear and (b) zigzag ordering of cations. Red denotes oxygen, blue and yellow denote the two different cations. Lithium is omitted for clarity. 
$\mathrm{LiNi}_{0.5} \mathrm{Co}_{0.5} \mathrm{O}_{2}$ and $\mathrm{LiNi}_{0.5} \mathrm{Al}_{0.5} \mathrm{O}_{2}$ the linear ordering of cations with space group symmetry $P 2 / m$ is found to be more energetically favorable than the zigzag ordering and is therefore used for subsequent defect calculations. In $\mathrm{LiNi}_{0.5} \mathrm{Mn}_{0.5} \mathrm{O}_{2}$, the zigzag ordering of $\mathrm{Ni}$ and $\mathrm{Mn}$ with space group symmetry $\mathrm{P} 2 / \mathrm{C}$ is energetically more favorable, in agreement with a previous theoretical study. ${ }^{25}$
Fig. 2 shows the calculated density of states for each material. The insulating behaviour of these compounds is well reproduced with band gaps of about $0.7 \mathrm{eV}, 0.9 \mathrm{eV}$ and $1.1 \mathrm{eV}$ for $\mathrm{LiNi}_{0.5} \mathrm{Co}_{0.5} \mathrm{O}_{2}, \mathrm{LiNi}_{0.5} \mathrm{Al}_{0.5} \mathrm{O}_{2}$ and $\mathrm{LiNi}_{0.5} \mathrm{Mn}_{0.5} \mathrm{O}_{2}$, respectively. The local density of states (DOS) of $\mathrm{Ni}$ in $\mathrm{LiNi}_{0.5} \mathrm{Co}_{0.5} \mathrm{O}_{2}$ shows one empty spin-up and two empty spin-down states which indicates that the electronic configuration of $\mathrm{Ni}$ is $\mathrm{t}_{2 \mathrm{~g}}^{6} \mathrm{e}_{\mathrm{g}}^{1}(S=1 / 2)$, (a)

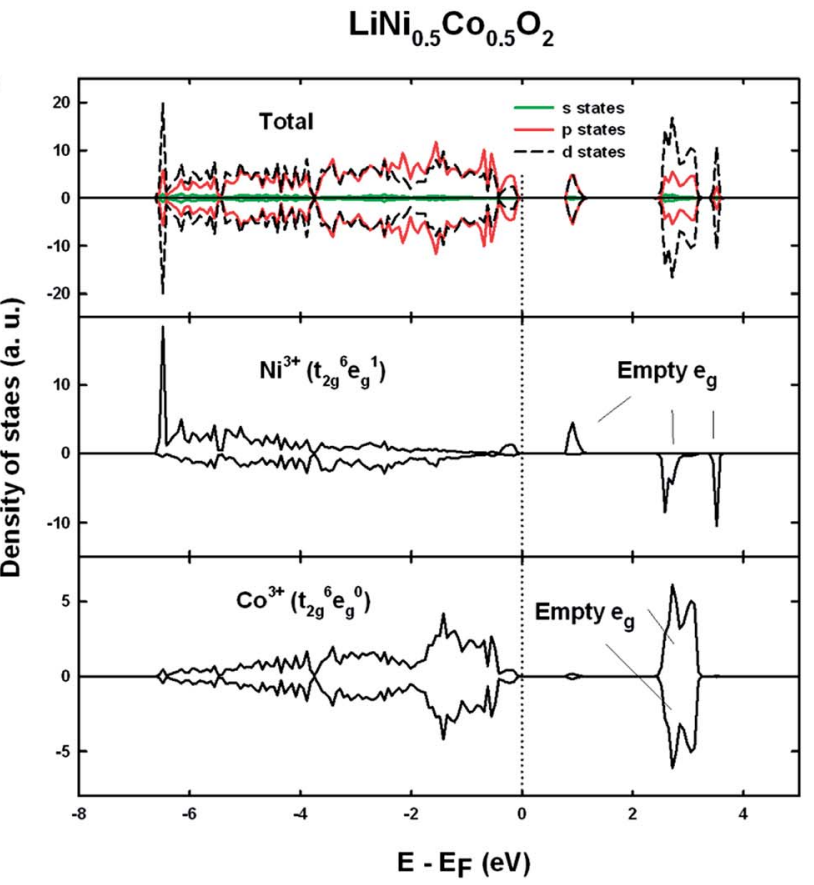

(b)

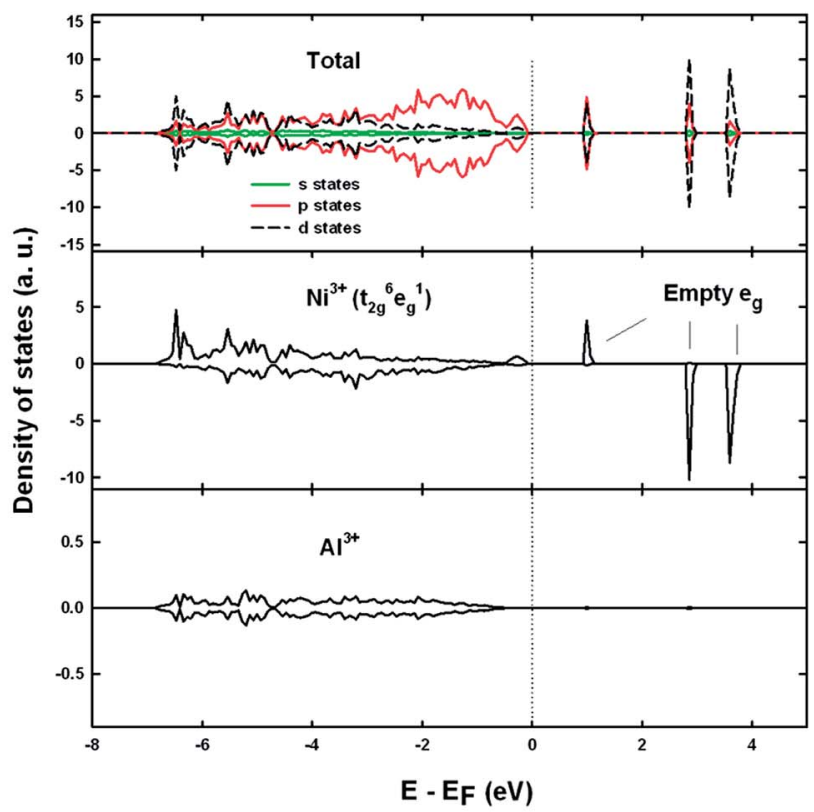

(c)

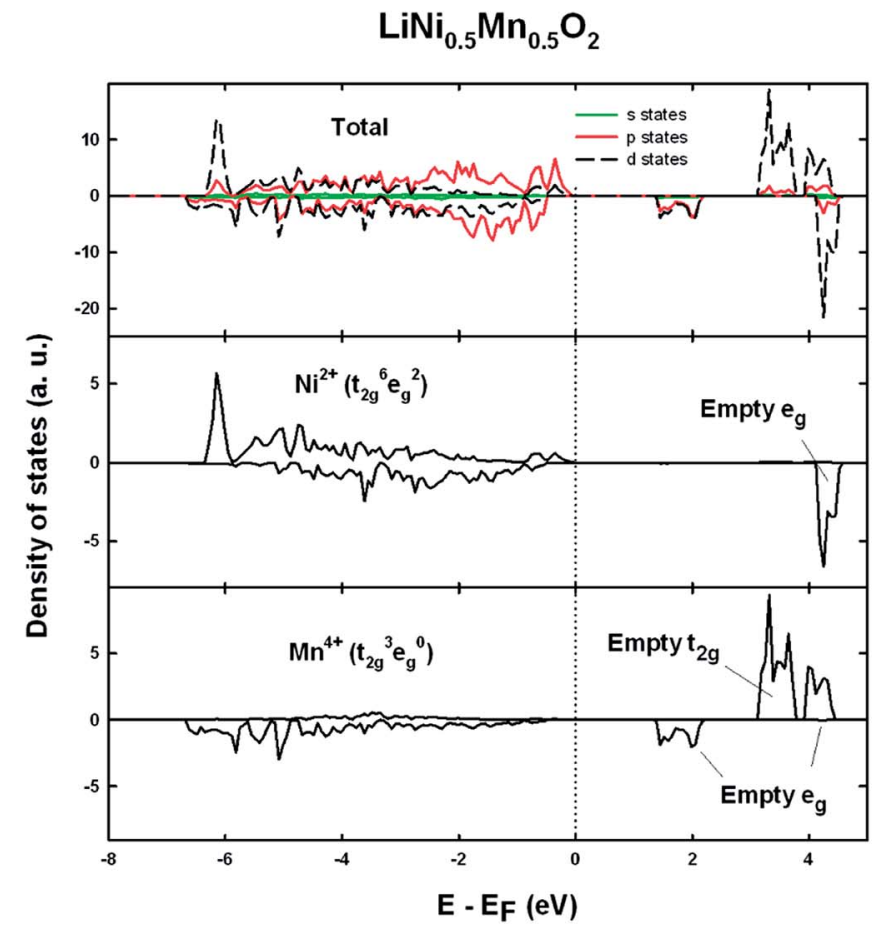

Fig. 2 Total density of states and local density of states on metal ions for (a) $\mathrm{LiNi}_{0.5} \mathrm{CO}_{0.5} \mathrm{O}_{2}$, (b) $\mathrm{LiNi}_{0.5} \mathrm{Al}_{0.5} \mathrm{O}_{2}$ and (c) $\mathrm{LiNi}_{0.5} \mathrm{Mn}_{0.5} \mathrm{O}_{2}$. 
which is low-spin $\mathrm{Ni}^{3+}$, in accordance with the calculated magnetic moment $1.12 \mu_{\mathrm{B}}$. A Jahn-Teller distortion occurs as expected for low-spin $\mathrm{Ni}^{3+}$ as shown from the $\mathrm{Ni}-\mathrm{O}$ bond lengths in Table 1. Cobalt ions are therefore anticipated to be $\mathrm{Co}^{3+}$ for the sake of charge neutrality. Indeed the empty spin-up and empty spin-down states from the local density of states of cobalt indicate that its electronic configuration is $\mathrm{t}_{2 \mathrm{~g}}^{6} \mathrm{e}_{\mathrm{g}}^{0}(S=0)$ implying low-spin $\mathrm{Co}^{3+}$, along with its calculated zero magnetic moment. Likewise, nickel ions are determined to be low spin $\mathrm{Ni}^{3+}$ in $\mathrm{LiNi}_{0.5} \mathrm{Al}_{0.5} \mathrm{O}_{2}$ with a Jahn-Teller distortion. Nevertheless, from the $\mathrm{Ni}^{3+}-\mathrm{O}$ bond lengths in Table 1 , it is clear that $\mathrm{Ni}^{3+}$ displays two different modes of Jahn-Teller distortion, $\mathrm{Q}_{2}$ and $\mathrm{Q}_{3}$ in $\mathrm{LiNi}_{0.5} \mathrm{Co}_{0.5} \mathrm{O}_{2}$ and $\mathrm{LiNi}_{0.5} \mathrm{Al}_{0.5} \mathrm{O}_{2}$ respectively, as shown in Fig. 3. The $\mathrm{Q}_{3}$ mode of Jahn-Teller distortion is the one observed in $\mathrm{LiNiO}_{2} \cdot{ }^{26} \mathrm{In}_{\mathrm{LiNi}}{ }_{0.5} \mathrm{Co}_{0.5} \mathrm{O}_{2}$, the low-spin $\mathrm{Co}^{3+}$ ions are very stable in the isotropic octahedral environment with 6 identical $\mathrm{Co}^{3+}$ $\mathrm{O}^{2-}$ bond lengths. The structural constraint imposed by the presence of rigid $\mathrm{Co}^{3+}$ octahedra makes the more distorted $\mathrm{Q}_{3}$ mode less favourable and results in the $\mathrm{Q}_{2}$ mode for distorted $\mathrm{Ni}^{3+}$. This result is in agreement with an EXAFS study that in $\mathrm{LiNi}_{1-y} \mathrm{Co}_{y} \mathrm{O}_{2}$ the Jahn-Teller distortion of $\mathrm{NiO}_{6}$ octohedra is suppressed with increasing $y .{ }^{27}$ In $\mathrm{LiNi}_{0.5} \mathrm{Mn}_{0.5} \mathrm{O}_{2}$, two empty spin-down $e_{g}$ states seen in the local density of states of nickel and fully-occupied spin-down $t_{2 \mathrm{~g}}$ states seen in the local density of states of manganese indicate that their electronic configurations are $\mathrm{t}_{2 \mathrm{~g}}^{6} \mathrm{e}_{\mathrm{g}}^{2}$ and $\mathrm{t}_{2 \mathrm{~g}}^{3} \mathrm{e}_{\mathrm{g}}^{0}$ corresponding to $\mathrm{Ni}^{2+}$ and $\mathrm{Mn}^{4+}$, in agreement with previously reported results. ${ }^{28}$

\section{Influence of defect formation on cation charge state}

In all $\mathrm{LiMO}_{2}$ cells with extra $\mathrm{Ni}$ and interlayer mixing defects, the calculated magnetic moment of $1.7 \mu_{\mathrm{B}}(S=1)$ for the Ni

Table 1 Calculated metal-oxygen bond lengths

\begin{tabular}{|c|c|c|c|c|c|}
\hline \multicolumn{2}{|c|}{$\mathrm{LiNi}_{0.5} \mathrm{Co}_{0.5} \mathrm{O}_{2}$} & \multicolumn{2}{|c|}{$\mathrm{LiNi}_{0.5} \mathrm{Al}_{0.5} \mathrm{O}_{2}$} & \multicolumn{2}{|c|}{$\mathrm{LiNi}_{0.5} \mathrm{Mn}_{0.5} \mathrm{O}_{2}$} \\
\hline & $\begin{array}{l}\text { Bond length } \\
\text { (A) }\end{array}$ & & $\begin{array}{l}\text { Bond length } \\
\text { (A) }\end{array}$ & & $\begin{array}{l}\text { Bond length } \\
\text { (A) }\end{array}$ \\
\hline \multirow[t]{3}{*}{$\mathrm{Ni}^{3+}-\mathrm{O}$} & $1.88 \times 2$ & $\mathrm{Ni}^{3+}-\mathrm{O}$ & $1.91 \times 2$ & $\mathrm{Ni}^{2+}-\mathrm{O}$ & $2.06 \times 2$ \\
\hline & $1.95 \times 2$ & & $1.92 \times 2$ & & $2.08 \times 2$ \\
\hline & $2.08 \times 2$ & & $2.11 \times 2$ & & $2.09 \times 2$ \\
\hline$\left\langle\mathrm{Ni}^{3+}-\mathrm{O}\right\rangle$ & 1.97 & $\left\langle\mathrm{Ni}^{3+}-\mathrm{O}\right\rangle$ & 1.97 & $\left\langle\mathrm{Ni}^{2+}-\mathrm{O}\right\rangle$ & 2.08 \\
\hline \multirow[t]{3}{*}{$\mathrm{Co}^{3+}-\mathrm{O}$} & $1.94 \times 6$ & $\mathrm{Al}^{3+}-\mathrm{O}$ & $1.90 \times 2$ & $\mathrm{Mn}^{4+}-\mathrm{O}$ & $1.92 \times 2$ \\
\hline & & & $1.93 \times 2$ & & $1.95 \times 2$ \\
\hline & & & $1.96 \times 2$ & & $1.98 \times 2$ \\
\hline$\left\langle\mathrm{Co}^{3+}-\mathrm{O}\right\rangle$ & 1.94 & $\left\langle\mathrm{Al}^{3+}-\mathrm{O}\right\rangle$ & 1.93 & $\left\langle\mathrm{Mn}^{4+}-\mathrm{O}\right\rangle$ & 1.95 \\
\hline
\end{tabular}

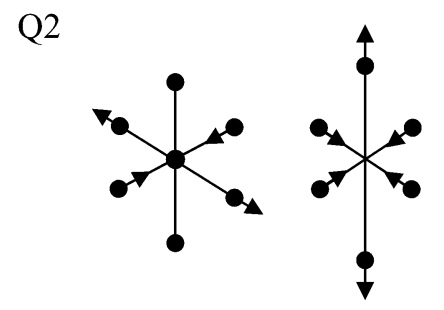

Q3

Fig. 3 Two modes of Jahn-Teller distortion. present in the Li layer along with its average $\mathrm{Ni}-\mathrm{O}$ bond length $2.07 \AA$ together imply that Nickel is present as $\mathrm{Ni}^{2+}$. Therefore in the $\mathrm{LiNiO}_{2}, \mathrm{LiNi}_{0.5} \mathrm{Co}_{0.5} \mathrm{O}_{2}$ and $\mathrm{LiNi}_{0.5} \mathrm{Al}_{0.5} \mathrm{O}_{2}$ cells with the interlayer mixing defect, in order to retain charge neutrality one $\mathrm{Ni}$ in the $\mathrm{NiO}_{2}$ slab is oxidised from $\mathrm{Ni}^{3+}$ to $\mathrm{Ni}^{4+}$ with a calculated magnetic moment $0.19 \mu_{\mathrm{B}}(S=0)$, as seen in the spin density contour map in Fig. 4(a), and the average $\mathrm{Ni}-\mathrm{O}$ bond length of $1.89 \AA$ A. In the $\mathrm{LiNi}_{0.5} \mathrm{Mn}_{0.5} \mathrm{O}_{2}$ cell, the interlayer mixing defect does not cause any change of charge state as nickel ions are already $\mathrm{Ni}^{2+}$.

In cells with the extra $\mathrm{Ni}$ defect, since one $\mathrm{Li}^{+}$is replaced by $\mathrm{Ni}^{2+}$, one metal ion in the $\mathrm{MO}_{2}$ layer must be reduced to maintain charge neutrality. In the $\mathrm{LiNiO}_{2}, \mathrm{NaNiO}_{2}, \mathrm{LiNi}_{0.5^{-}}$ $\mathrm{Co}_{0.5} \mathrm{O}_{2}$ and $\mathrm{LiNi}_{0.5} \mathrm{Al}_{0.5} \mathrm{O}_{2}$ cells, it is the $\mathrm{Ni}$ in the $\mathrm{MO}_{2}$ layer that gets reduced from $\mathrm{Ni}^{3+}$ to $\mathrm{Ni}^{2+}$ with a calculated magnetic moment of $1.7 \mu_{\mathrm{B}}(S=0)$ and an average Ni-O bond length of $2.07 \AA$. The change of preferred charge state on Ni rather than Co in $\mathrm{LiNi}_{0.5} \mathrm{Co}_{0.5} \mathrm{O}_{2}$ is probably due to the relatively stable electronic configuration of $\mathrm{Co}^{3+}\left(\mathrm{t}_{2 \mathrm{~g}}^{6} \mathrm{e}_{\mathrm{g}}^{0}\right)$. In $\mathrm{LiNi}_{0.5} \mathrm{Mn}_{0.5} \mathrm{O}_{2}$, the charge state of $\mathrm{Ni}^{2+}$ cannot be reduced further and therefore the charge compensation accompanied by the extra Ni defect takes place on manganese with $\mathrm{Mn}^{4+} \rightarrow \mathrm{Mn}^{3+}$. Fig. 4(b) shows the case of the extra-Ni defect in $\mathrm{LiNi}_{0.5} \mathrm{Mn}_{0.5} \mathrm{O}_{2}$. The $\mathrm{e}_{\mathrm{g}}$ orbital character on $\mathrm{Ni}^{2+}\left(\mathrm{t}_{2 \mathrm{~g}}^{6} \mathrm{e}_{\mathrm{g}}^{2}\right)$ can be seen from the shape of spin density pointing towards oxygen ions. Similarly, the spin density on $\mathrm{Mn}^{4+}\left(\mathrm{t}_{2 \mathrm{~g}}^{3} \mathrm{e}_{\mathrm{g}}^{0}\right)$ pointing away from the oxygen represents the $t_{2 g}$ orbital character. The Mn ion showing the different shape of spin density is the one that is reduced from $\mathrm{Mn}^{4+}$ to $\mathrm{Mn}^{3+}$.

For cells with the oxygen vacancy defect, two metal ions in the $\mathrm{MO}_{2}$ layer next to the oxygen vacancy site are reduced to keep the charge neutrality. Fig. 4(c) clearly shows that two $\mathrm{Co}^{3+}$ ions are reduced to $\mathrm{Co}^{2+}$ upon the removal of one oxygen ion.

\section{Stability of defects and the effect of cation substitution}

The calculated defect formation energies in $\mathrm{LiNiO}_{2}$ are shown in Fig. 5. The calculated formation energies of the three defects in $\mathrm{LiNiO}_{2}$ are all small, ranging from approximately 0.3 to $1.0 \mathrm{eV}$. This is consistent with the difficulty in synthesizing stoichiometric defect-free $\mathrm{LiNiO}_{2}$. It is possible to rationalize these results using the idea of superexchange interactions. ${ }^{29-31}$ Both $\mathrm{Ni}^{2+}\left(\mathrm{t}_{2 \mathrm{~g}}^{6} \mathrm{e}_{\mathrm{g}}^{2}\right)$ and $\mathrm{Ni}^{3+}\left(\mathrm{t}_{2 \mathrm{~g}}^{6} \mathrm{e}_{\mathrm{g}}^{1}\right)$ have fully filled $\mathrm{t}_{2 \mathrm{~g}}$ states but partially filled $\mathrm{e}_{\mathrm{g}}$ states. Consequently the $180^{\circ} \mathrm{Ni}-\mathrm{O}-\mathrm{Ni}$ superexchange is much stronger than the $90^{\circ} \mathrm{Ni}-\mathrm{O}-\mathrm{Ni}$ superexchange plus direct exchange. This means there is a larger energy gain through orbital interactions when $\mathrm{Ni}-\mathrm{O}-\mathrm{N}$ is in the $180^{\circ}$ configuration than the $90^{\circ}$ configuration. In fact it has been shown that there is a tendency for $\mathrm{Ni}$ ions to locate as secondnearest neighbors $\left(180^{\circ} \mathrm{Ni}-\mathrm{O}-\mathrm{Ni}\right.$ configuration $)$ in the cation sublattice of the rocksalt structure due to the energy gain from the $180^{\circ}$ superexchange interaction. ${ }^{32}$ Therefore the presence of $\mathrm{Ni}$ ions in the $\mathrm{Li}$ layers of $\mathrm{LiNiO}_{2}$ can be viewed as being stabilized by the $180^{\circ} \mathrm{Ni}-\mathrm{O}-\mathrm{Ni}$ superexchange interaction, giving rise to low formation energies for both interlayer mixing and the extra Ni defects. However, the extra Ni defect is the most 

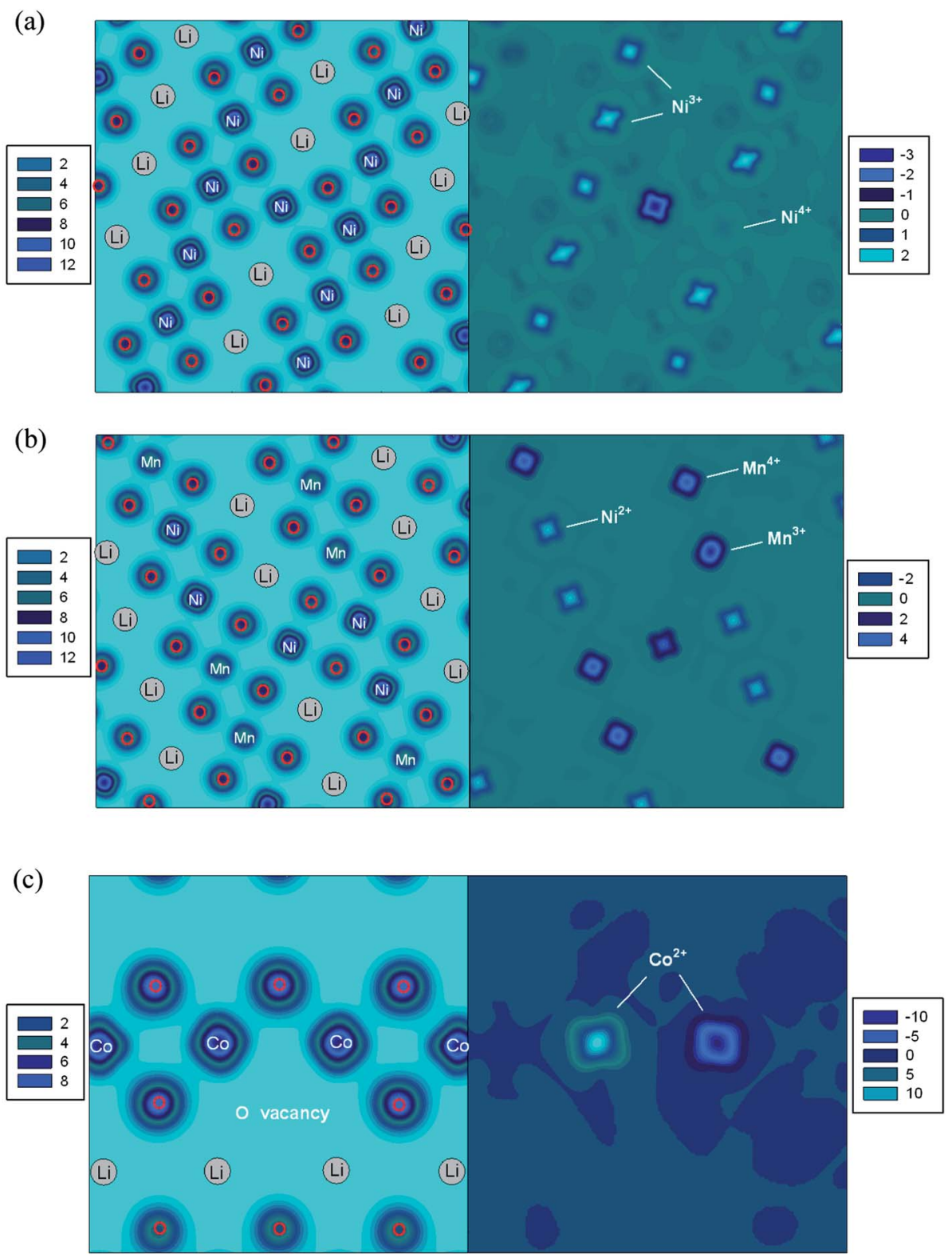

Fig. 4 Charge density (left) and spin density (right) contour maps (e $\AA^{-3}$ ) of $\mathrm{LiNiO}_{2}$ with the (a) $\mathrm{Li}-\mathrm{Ni}$ anti-site defect, (b) $\mathrm{LiNi}_{0.5} \mathrm{Mn}_{0.5} \mathrm{O}_{2}$ with the extra-Ni defect and (c) $\mathrm{LiCoO}_{2}$ with the oxygen vacancy defect.

favorable and therefore is the predominant defect species in $\mathrm{LiNiO}_{2}$.

In $\mathrm{LiNi}_{0.5} \mathrm{Co}_{0.5} \mathrm{O}_{2}$ and $\mathrm{LiNi}_{0.5} \mathrm{Al}_{0.5} \mathrm{O}_{2}$, due to the linear cation ordering in the transition metal plane, there are two inequivalent $\mathrm{Li}$ sites on which to place the $\mathrm{Ni}$ in the interlayer mixing and the extra Ni defects, as shown in Fig. 6. These are referred to as configurations $\mathrm{A}$ and $\mathrm{B}$. In $\mathrm{LiNi}_{0.5} \mathrm{Mn}_{0.5} \mathrm{O}_{2}$, the zigzag ordering of $\mathrm{Ni}$ and $\mathrm{Mn}$ also results in two inequivalent $\mathrm{Li}$ sites referred to as A and B. Similarly in the cells of $\mathrm{LiNi}_{0.5} \mathrm{Co}_{0.5} \mathrm{O}_{2}$, $\mathrm{LiNi}_{0.5} \mathrm{Al}_{0.5} \mathrm{O}_{2}$ and $\mathrm{LiNi}_{0.5} \mathrm{Mn}_{0.5} \mathrm{O}_{2}$, there are two inequivalent oxygen ions, one bonding with two $\mathrm{Ni}$ and one bonding with one $\mathrm{Ni}$, in the cell, which can be removed to create the oxygen vacancy. We refer to the removal of the oxygen bonded to two $\mathrm{Ni}$ as configuration A and the removal of the oxygen bonded to only one $\mathrm{Ni}$ as configuration $\mathrm{B}$.
The effect of Co substitution can be seen in Fig. 5(a). It is first noted that the defect formation energies of the interlayer mixing and the extra $\mathrm{Ni}$ defects in $\mathrm{LiNi}_{0.5} \mathrm{Co}_{0.5} \mathrm{O}_{2}$ with configuration A are lower than in $\mathrm{LiNiO}_{2}$. This is unexpected since it is known experimentally that Co substitution in $\mathrm{LiNiO}_{2}$ suppresses the presence of $\mathrm{Ni}$ in the $\mathrm{Li}$ layer. Nevertheless the formation energies of the interlayer mixing and extra Ni defects are higher in configuration B than configuration A by about $300 \mathrm{meV}$ and $360 \mathrm{meV}$ respectively. The result can also be rationalized by considering superexchange interactions. As seen in Fig. 6(a), in configuration $\mathrm{A}$, the $\mathrm{Ni}$ in the Li layer forms six $180^{\circ} \mathrm{Ni}-\mathrm{O}-\mathrm{Ni}$ chains. In configuration $\mathrm{B}$, the $\operatorname{six} 2^{\text {nd }}$-nearest-neighbours in the cation sublattice, of the $\mathrm{Ni}$ in the $\mathrm{Li}$ layer are $\mathrm{Co}^{3+}$, forming $180^{\circ}$ $\mathrm{Ni}-\mathrm{O}-\mathrm{Co}$ chains which do not give rise to the $180^{\circ}$ superexchange interaction due to the empty $\mathrm{e}_{\mathrm{g}}$ orbitals of $\mathrm{Co}^{3+}\left(\mathrm{t}_{2 \mathrm{~g}}^{6} \mathrm{e}_{\mathrm{g}}^{0}\right)$. 
(a)

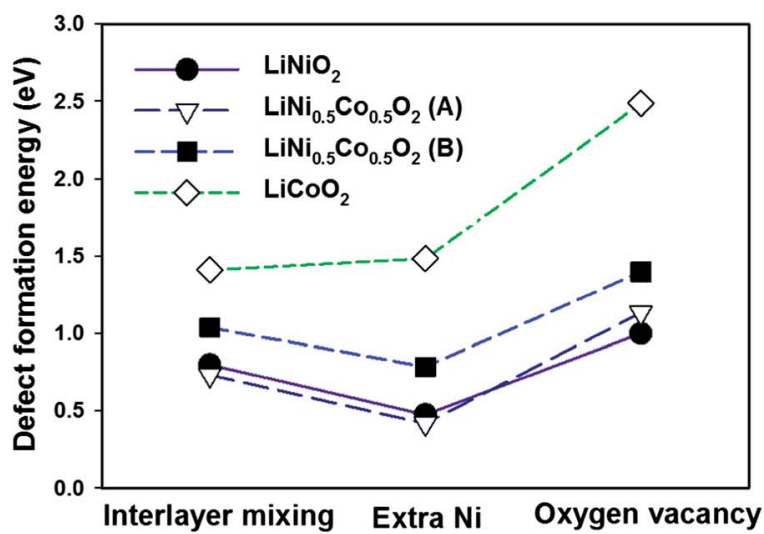

(b)

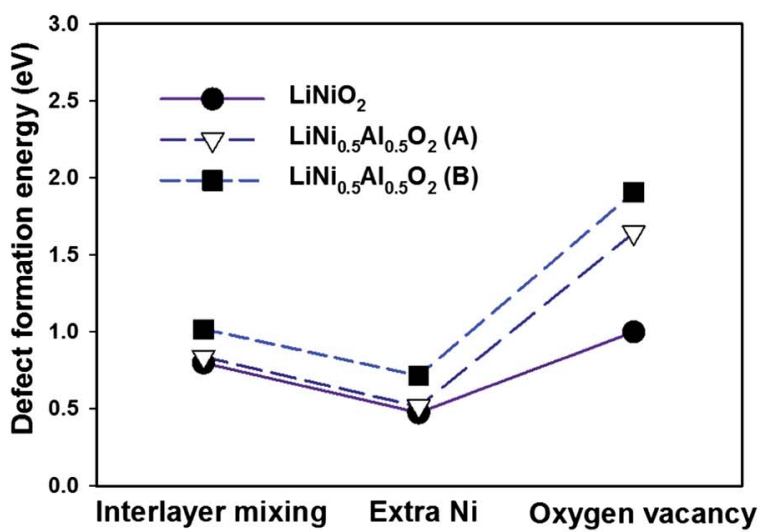

Fig. 5 The effect of (a) Co and (b) Al substitution on the calculated defect formation energies.
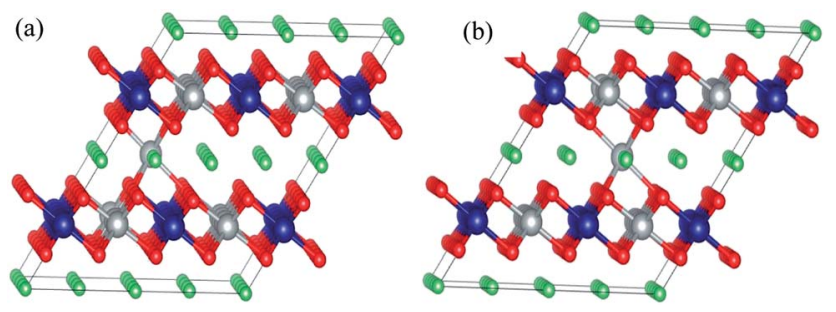

Fig. 6 Two inequivalent positions in the Li layer: (a) configuration A and (b) configuration $\mathrm{B}$. The grey spheres denote $\mathrm{Ni}$, the blue spheres denote $\mathrm{Co}$, the green spheres denote $\mathrm{Li}$ and the red spheres denote $\mathrm{O}$.

This again suggests that the presence of $\mathrm{Ni}^{2+}$ in the $\mathrm{Li}$ layer is stabilized by the $180^{\circ} \mathrm{Ni}-\mathrm{O}-\mathrm{Ni}$ superexchange interaction. The higher number of the $180^{\circ} \mathrm{Ni}-\mathrm{O}-\mathrm{Ni}$ chains gives rise to the lower energy. In the real $\mathrm{LiNi}_{0.5} \mathrm{Co}_{0.5} \mathrm{O}_{2}$ compound, the $\mathrm{Co}^{3+}$ ions distribute randomly in the $\mathrm{MO}_{2}$ slab and the main effect of cobalt substitution would be to screen the $180^{\circ} \mathrm{Ni}-\mathrm{O}-\mathrm{Ni}$ superexchange interaction. This is different from a previous proposed size effect, ${ }^{15}$ and destabilizes the presence of $\mathrm{Ni}$ in the Li layer.

The defect formation energies in $\mathrm{LiCoO}_{2}$ are also shown in Fig. 5(a). The defect energies of the interlayer mixing defect and the extra Co defect are considerably higher than the $\mathrm{Ni}$ containing compounds. This agrees with the experimentally observed perfect layering of $\mathrm{LiCoO}_{2}$. Given the closed-shell $\mathrm{d}^{6}\left(\mathrm{t}_{2 \mathrm{~g}}^{6} \mathrm{e}_{\mathrm{g}}^{0}\right)$ electronic configuration of $\mathrm{Co}^{3+}$ in the $\mathrm{CoO}_{2}$ layer, there is no interaction between Co ions that can stabilize the presence of Co in the Li layer.

Since there are no d electrons in the $\mathrm{Al}^{3+}$ ion, there can be no superexchange interaction between $\mathrm{Al}^{3+}$ and $\mathrm{Ni}^{2+}$. The effect of Al substitution on defect formation energies is therefore expected to be similar to that of Co substitution since $\mathrm{Al}$ substitution should also effectively screen the Ni-O-Ni superexchange interaction. Indeed by adopting the linear cation ordering in the $\mathrm{LiNi}_{0.5} \mathrm{Al}_{0.5} \mathrm{O}_{2}$ cell (Fig. 1(a)), as shown in Fig. 5(b) the calculated formation energies of the interlayer mixing and the extra Ni defects are very similar to those in $\mathrm{LiNi}_{0.5} \mathrm{Co}_{0.5} \mathrm{O}_{2}$. Defects of configuration $\mathrm{A}$ are also more favourable than configuration $\mathrm{B}$ due to the stabilisation by the exchange interaction. However, unlike in $\mathrm{LiNi}_{1-x} \mathrm{Co}_{x} \mathrm{O}_{2}$ with $x>$ 0.3 , neither the interlayer mixing defect nor extra Ni defects are observed..$^{15}$ Experimentally 5\% of extra-nickel ions are still found in the lithium layer in $\operatorname{LiNi}_{1-x} \mathrm{Al}_{x} \mathrm{O}_{2}$ with $0.1<x<0.5 .{ }^{19}$ This is because $\mathrm{Al}$ tends to segregate to interfaces ${ }^{33}$ and hence a core-shell structure can be formed ${ }^{34}$ in $\mathrm{LiNi}_{0.5} \mathrm{Al}_{0.5} \mathrm{O}_{2}$. Consequently, the extra-Ni and $\mathrm{Li}-\mathrm{Ni}$ anti-site defects can still occur in Ni-rich domains in $\mathrm{LiNi}_{0.5} \mathrm{Al}_{0.5} \mathrm{O}_{2}$ as in $\mathrm{LiNiO}_{2}$, where the presence of $\mathrm{Ni}$ in the $\mathrm{Li}$ layer can be stabilized by the $180^{\circ} \mathrm{Ni}-\mathrm{O}-\mathrm{Ni}$ exchange interaction.

As shown by Fig. 7(a) there is no significant difference in configurations $\mathrm{A}$ and $\mathrm{B}$ for the formation energy of the interlayer mixing and the extra Ni defects in $\mathrm{LiNi}_{0.5} \mathrm{Mn}_{0.5} \mathrm{O}_{2}$. The formation energy of the interlayer mixing is markedly lower than that of the extra-Ni defect. This is consistent with the experimentally observed high concentration of interlayered mixing defects in $\mathrm{LiNi}_{0.5} \mathrm{Mn}_{0.5} \mathrm{O}_{2}$. Also the formation energy of the interlayer mixing defect is lower by about $0.3 \mathrm{eV}$ than that of $\mathrm{LiNiO}_{2}$. Unlike in $\mathrm{LiNi}_{0.5} \mathrm{Co}_{0.5} \mathrm{O}_{2}$ and $\mathrm{LiNi}_{0.5} \mathrm{Al}_{0.5} \mathrm{O}_{2}$ where the $180^{\circ} \mathrm{Ni}-$ $\mathrm{O}-\mathrm{Co}$ and $180^{\circ} \mathrm{Ni-O}-\mathrm{Al}$ interactions are absent, in $\mathrm{LiNi}_{0.5} \mathrm{Mn}_{0.5} \mathrm{O}_{2}$ the electronic configuration of $\mathrm{Mn}^{4+}\left(\mathrm{t}_{2 \mathrm{~g}}^{3} \mathrm{e}_{\mathrm{g}}^{\mathrm{o}}\right)$ could give rise to moderate $180^{\circ} \mathrm{Ni}^{2+}-\mathrm{O}^{2-}-\mathrm{Mn}^{4+}$ interactions. ${ }^{31}$ Consequently, although the number of $180^{\circ} \mathrm{Ni}-\mathrm{O}-\mathrm{Ni}$ interactions is reduced due to $\mathrm{Mn}$ substitution, the presence of $\mathrm{Ni}^{2+}$ can be stabilized not only by the $180^{\circ} \mathrm{Ni}-\mathrm{O}-\mathrm{Ni}$ interaction but also by the $180^{\circ} \mathrm{Ni}^{2+}-\mathrm{O}^{2-}-\mathrm{Mn}^{4+}$ interaction. Moreover, since the ionic radius of $\mathrm{Ni}^{2+}$ is similar to $\mathrm{Li}^{+}$, these ions can exchange sites readily without significant rearrangement of the surrounding atomic positions. No charge compensation is necessary to create the interlayer mixing defect in $\mathrm{LiNi}_{0.5} \mathrm{Mn}_{0.5} \mathrm{O}_{2}$. In contrast to the interlayer mixing defect, the defect formation energy for the extra Ni defect is much higher in $\mathrm{LiNi}_{0.5} \mathrm{Mn}_{0.5} \mathrm{O}_{2}$ compared to $\mathrm{LiNiO}_{2}$. The probable reason for this is that the reduction of $\mathrm{Mn}^{4+}$ to $\mathrm{Mn}^{3+}$, which is the charge compensation accompanying the extra-Ni defect, is considerably less favorable than the reduction of $\mathrm{Ni}^{3+}$ to $\mathrm{Ni}^{2+}$ due to the stable electronic configuration of $\mathrm{Mn}^{4+}\left(\mathrm{t}_{2 \mathrm{~g}}^{3} \mathrm{e}_{\mathrm{g}}^{0}\right)$.

In $\mathrm{NaNiO}_{2}$, there is a structural constraint arising from the large ionic size of $\mathrm{Na}^{+}$. It is shown in Table 2 that the $\mathrm{LiO}_{6}$ octahedron must undergo significant distortion for the zigzag ordering of the $\mathrm{Ni}^{3+}$ Jahn-Teller distortions or charge 
(a)

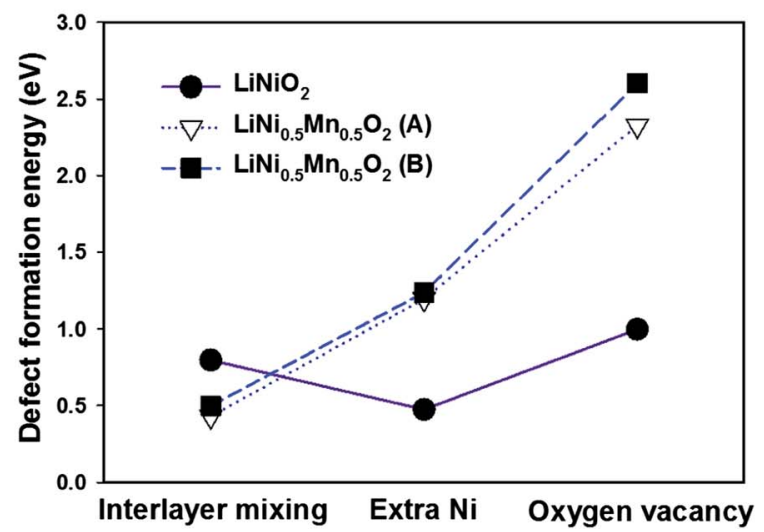

(b)

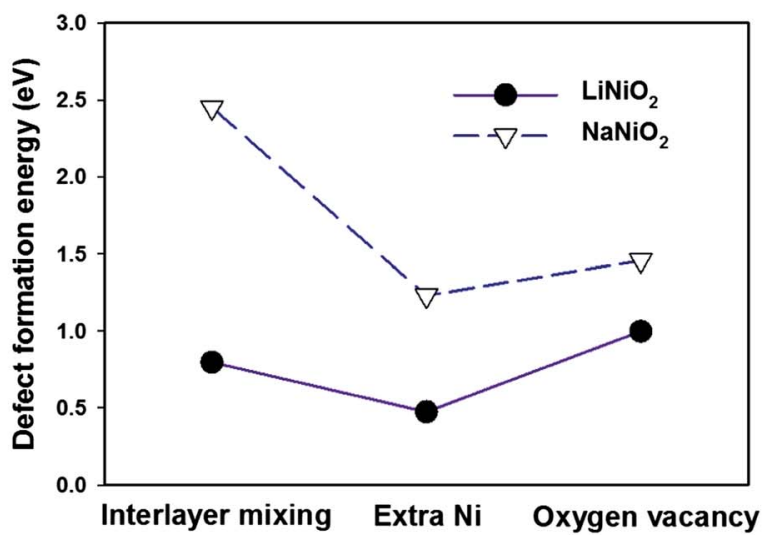

Fig. 7 Calculated defect formation energies in (a) $\mathrm{LiNi}_{0.5} \mathrm{Mn}_{0.5}$ and (b) $\mathrm{NaNiO}_{2}$ compared to $\mathrm{LiNiO}_{2}$.

Table $2 \mathrm{Li}-\mathrm{O}$ bond lengths in the three different $\mathrm{LiNiO}_{2}$ cells

Structure

$C 2 / m$ (collinear ordering of the $\mathrm{Ni}^{3+}$

Jahn-Teller distortions)

$P 2_{1} / c$ (zigzag ordering of the $\mathrm{Ni}^{3+}$

Jahn-Teller distortions)

$P 2 / c$ (charge disproportionation

$\left.\mathrm{Ni}^{3+} \rightarrow \mathrm{Ni}^{2+}+\mathrm{Ni}^{4+}\right)$

\section{Oxygen vacancy}

Fig. 8 shows the calculated defect formation energies of the oxygen vacancy plotted against the oxygen charge calculated using the Bader analysis..$^{35,36}$ The formal charge on oxygen is -2 in highly ionic compounds. However, in transition metal oxides, there is a considerable overlap between the oxygen $2 \mathrm{p}$ and metal $3 \mathrm{~d}$ orbitals, particularly for late transition metals or metals with high charge states. This is reflected in the calculated oxygen charge as shown in Fig. 8, from left to right $\left(\mathrm{LiAlO}_{2} \rightarrow \mathrm{LiNiO}_{2}\right.$ and $\mathrm{LiCoO}_{2} \rightarrow \mathrm{Li}_{0.5} \mathrm{CoO}_{2}$ ) the decrease of calculated oxygen charge is a consequence of the increase in overlap between oxygen $2 \mathrm{p}$ and metal ion $3 \mathrm{~d}$ orbitals or equivalently greater metal-oxygen covalency. A correlation can be clearly seen between the formation energy of the oxygen vacancy defect and the calculated oxygen charge. Also, as shown in Fig. 5 and 7 , in $\mathrm{LiNi}_{0.5} \mathrm{Co}_{0.5} \mathrm{O}_{2}$, $\mathrm{LiNi}_{0.5} \mathrm{Al}_{0.5} \mathrm{O}_{2}$ and $\mathrm{LiNi}_{0.5} \mathrm{Mn}_{0.5} \mathrm{O}_{2}$, the defect formation energy for removing the oxygen bonded to two $\mathrm{Ni}$ (configuration $\mathrm{A}$ ) is lower than the oxygen bonded to one Ni (configuration B). The oxygen bonded to two Ni has a lower charge. The smaller the oxygen charge is, the easier it seems to be to remove the oxygen. It has previously been suggested that the strength of the metal-oxygen bond depends on the effective charge on oxygen. ${ }^{37}$ In addition when the charge on oxygen ions is low, there would be a tendency for them to form peroxide at the surface as suggested by Goodenough et $a l .{ }^{38}$ and then dissociate through the following reaction:

$$
2\left(\mathrm{O}_{2}\right)^{2-}=2 \mathrm{O}^{2-}+\mathrm{O}_{2}
$$

This is consistent with experimental results that the temperature for oxygen evolution on heating (i.e. the thermal stability) decreases as $x$ decreases in layered $\mathrm{Li}_{x} \mathrm{MO}_{2} \cdot{ }^{39-41}$ It seems that low oxygen charge/high metal-oxygen covalency causes the chemical instability of an oxide compound against oxygen loss. A recent study has also proposed that a greater metal-oxygen covalency promotes the surface oxygen evolution reaction which involves the creation of surface oxygen vacancies. ${ }^{42}$

On comparing $\mathrm{LiNiO}_{2}$ with $\mathrm{LiCoO}_{2}$ there is no noticeable difference in the oxygen charge, but the defect formation energy

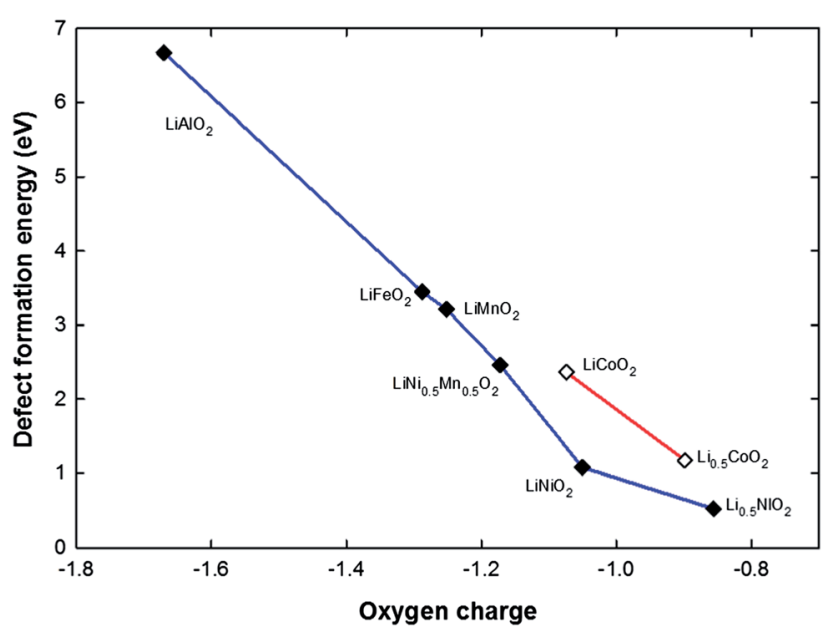

Fig. 8 The correlation between oxygen charge and defect formation energy for an oxygen vacancy for a series of structures. disproportionation $\mathrm{Ni}^{3+} \rightarrow \mathrm{Ni}^{2+}+\mathrm{Ni}^{4+}$ in the $\mathrm{NiO}_{2}$ layer to happen. However, the larger $\mathrm{Na}^{+}$ion fills up the interlayer space and so forbids the zigzag ordering of the $\mathrm{Ni}^{3+}$ Jahn-Teller distortions or charge disproportionation $\mathrm{Ni}^{3+} \rightarrow \mathrm{Ni}^{2+}+\mathrm{Ni}^{4+}$ in the $\mathrm{NiO}_{2}$ layer. Hence the $\mathrm{Ni}^{3+}$ Jahn-Teller distortions in $\mathrm{NaNiO}_{2}$ are forced to align collinearly as observed experimentally, which results in undistorted $\mathrm{NaO}_{6}$ octahedra. This gives a good 2-D layered character and is less susceptible to defects as shown by the high defect formation energies for $\mathrm{NaNiO}_{2}$ compared to $\mathrm{LiNiO}_{2}$ in Fig. 7(b). Because of the dramatic difference in ionic radii between $\mathrm{Na}$ and first-row transition metal ions, the size effect dominates the interactions between cations and consequently all $\mathrm{NaMO}_{2}$ form perfect layered structures.
$\mathrm{Li}-\mathrm{O}$ bond

$2.11 \times 4$

$2.04 \times 2$

$24 \times 2$

$2.03 \times 2$

$2.08 \times 2$ 
of the oxygen vacancy in $\mathrm{LiCoO}_{2}$ is significantly higher than in $\mathrm{LiNiO}_{2}$ (by $\sim 1.2 \mathrm{eV}$ ). This is probably due to the relatively stable electronic configuration of low-spin $\mathrm{Co}^{3+} \mathrm{t}_{2 \mathrm{~g}}^{6} \mathrm{e}_{\mathrm{g}}^{0}$. Therefore by creating an oxygen vacancy, it costs more energy to reduce $\mathrm{Co}^{3+}$ to $\mathrm{Co}^{2+}$ than to reduce $\mathrm{Ni}^{3+}$ to $\mathrm{Ni}^{2+}$ in $\mathrm{LiNiO}_{2}$. Although the defect formation energy of an oxygen vacancy in $\mathrm{LiCoO}_{2}$ is markedly higher than in $\mathrm{LiNiO}_{2}$, it drops drastically by $\sim 1.5 \mathrm{eV}$ in $\mathrm{Li}_{0.5} \mathrm{CoO}_{2}$ upon the removal of half the lithium ions. This can again be explained by the decrease of oxygen charge that is associated with the creation of $\mathrm{Co}^{4+}$ ions.

Given this correlation between oxygen charge and the defect formation energy of the oxygen vacancy, doping with a more electro-positive cation should mitigate the oxygen loss in layered $\mathrm{Li}_{x} \mathrm{MO}_{2}$ compounds and result in better thermal stability. Indeed doping with $\mathrm{Mn}^{4+}$ decreases the oxygen loss ${ }^{43}$ and so does $\mathrm{Al}$ or $\mathrm{Mg}$ doping, ${ }^{18,44,45}$ or $\mathrm{Ti}^{4+}$ substitution for $\mathrm{Mn}^{4+}$ in $\mathrm{Li}\left[\mathrm{Li}_{0.33} \mathrm{Mn}_{0.67-x} \mathrm{Ti}_{x}\right] \mathrm{O}_{2}{ }^{46}$

\section{Conclusions}

All the calculated formation energies for the various $\mathrm{LiMO}_{2}$ compounds are consistent with experimental results. It is demonstrated that the defect formation energies in $\mathrm{LiNiO}_{2}$ are low, in agreement with the experimental difficulty of synthesizing stoichiometric defect-free $\mathrm{LiNiO}_{2}$. The presence of $\mathrm{Ni}$ in the $\mathrm{Li}$ layer can be rationalized in terms of the $180^{\circ} \mathrm{Ni}-\mathrm{O}-\mathrm{Ni}$ superexchange interaction. Substituting $\mathrm{Ni}$ with $\mathrm{Co}$ in the $\mathrm{MO}_{2}$ layer screens the $180^{\circ} \mathrm{Ni}-\mathrm{O}-\mathrm{Ni}$ configurations and thus effectively reduces the concentration of $\mathrm{Ni}$ in $\mathrm{Li}$ layers. A correlation between the defect formation energy of the oxygen vacancy and oxygen charge (as measured from a Bader analysis) is reported. It appears that the smaller the oxygen charge/higher metaloxygen covalency, the lower the oxygen vacancy formation energy. This can explain the thermal instability of $\mathrm{Li}_{x} \mathrm{CoO}_{2}$ and $\mathrm{Li}_{x} \mathrm{NiO}_{2}$ at low $x$, as well as the improved electrochemical behavior in $\mathrm{Al}, \mathrm{Mg}$ or early transition metal doped $\mathrm{LiMO}_{2}$. In the quest for designing better cathode materials, the use of high electropositive cations is highly desirable.

\section{Acknowledgements}

We thank EPSRC for funding under Grant number - EP/ G005001/1. Via our membership of the UK's HPC Materials Chemistry Consortium, which is funded by EPSRC (EP/ F067496), this work made use of the facilities of HECToR, the UK's national high-performance computing service, which is provided by UoEHPCx Ltd at the University of Edinburgh, Cray Inc and NAG Ltd, and funded by the Office of Science and Technology through EPSRC's High End Computing Programme.

\section{References}

1 J. H. Chung, T. Proffen, S. Shamoto, A. M. Ghorayeb, L. Croguennec, W. Tian, B. C. Sales, R. Jin, D. Mandrus and T. Egami, Phys. Rev. B: Condens. Matter Mater. Phys, 2005, 71(6), 064410.
2 H. Chen, C. L. Freeman and J. H. Harding, Phys. Rev. B: Condens. Matter Mater. Phys., 2011, 84(8), 085108.

3 R. Kanno, H. Kubo, Y. Kawamoto, T. Kamiyama, F. Izumi, Y. Takeda and M. Takano, J. Solid State Chem., 1994, 110(2), 216-225.

4 Y. Koyama, H. Arai, I. Tanaka, Y. Uchimoto and Z. Ogumi, Chem. Mater., 2012, 24, 3886.

5 S. Venkatraman and A. Manthiram, Chem. Mater., 2003, 15(26), 5003-5009.

6 J.-M. Kim and H.-T. Chung, Electrochim. Acta, 2004, 49(6), 937-944.

7 H. Arai, S. Okada, H. Ohtsuka, M. Ichimura and J. Yamaki, Solid State Ionics, 1995, 80(3-4), 261-269.

8 J. P. Peres, C. Delmas, A. Rougier, M. Broussely, F. Perton, P. Biensan and P. Willmann, J. Phys. Chem. Solids, 1996, 57, 1057-1060.

9 S. Zheng, R. Huang, Y. Makimura, Y. Ukyo, C. A. J. Fisher, T. Hirayama and Y. Ikuhara, J. Electrochem. Soc., 2011, 158(4), A357-A362.

10 C. Delmas, J. P. Pérès, A. Rougier, A. Demourgues, F. Weill, A. Chadwick, M. Broussely, F. Perton, P. Biensan and P. Willmann, J. Power Sources, 1997, 68(1), 120-125.

11 M. S. Idris and A. R. West, J. Electrochem. Soc., 2012, 159(4), A396-A401.

12 K.-K. Lee, W.-S. Yoon, K.-B. Kim, K.-Y. Lee and S.-T. Hong, J. Power Sources, 2001, 97-98, 321-325.

13 S. Muto, Y. Sasano, K. Tatsumi, T. Sasaki, K. Horibuchi, Y. Takeuchi and Y. Ukyo, J. Electrochem. Soc., 2009, 156(5), A371-A377.

14 L. Wu, K.-W. Nam, X. Wang, Y. Zhou, J.-C. Zheng, X.-Q. Yang and Y. Zhu, Chem. Mater., 2011, 23(17), 39533960.

15 A. Rougier, I. Saadoune, P. Gravereau, P. Willmann and C. Delmasa, Solid State Ionics, 1996, 90(1-4), 83-90.

16 E. Rossen, C. D. W. Jones and J. R. Dahn, Solid State Ionics, 1992, 57(3-4), 311-318.

17 N. Yabuuchi, Y.-T. Kim, H. H. Li and Y. Shao-Horn, Chem. Mater., 2008, 20(15), 4936-4951.

18 M. Guilmard, L. Croguennec, D. Denux and C. Delmas, Chem. Mater., 2003, 15(23), 4476-4483.

19 M. Guilmard, A. Rougier, M. Grüne, L. Croguennec and C. Delmas, J. Power Sources, 2003, 115(2), 305-314.

20 G. Kresse and D. Joubert, Phys. Rev. B: Condens. Matter Mater. Phys., 1999, 59(3), 1758.

21 J. P. Perdew, K. Burke and M. Ernzerhof, Phys. Rev. Lett., 1996, 77(18), 3865.

22 S. L. Dudarev, G. A. Botton, S. Y. Savrasov, C. J. Humphreys and A. P. Sutton, Phys. Rev. B: Condens. Matter Mater. Phys., 1998, 57(3), 1505-1509.

23 F. Zhou, M. Cococcioni, C. A. Marianetti, D. Morgan and G. Ceder, Phys. Rev. B: Condens. Matter Mater. Phys., 2004, 70(23), 235121.

24 G. Kresse and J. Furthmüller, Phys. Rev. B: Condens. Matter Mater. Phys., 1996, 54(16), 11169-11186.

25 Y. Won-Sub, I. Steven, P. G. Clare, C. Dany, G. John, R. John and C. Gerbrand, Electrochem. Solid-State Lett., 2004, 7(7), A167-A171. 
26 A. Rougier, C. Delmas and A. V. Chadwick, Solid State Commun., 1995, 94(2), 123-127.

27 I. Nakai, K. Takahashi, Y. Shiraishi, T. Nakagome and F. Nishikawa, J. Solid State Chem., 1998, 140(1), 145-148.

28 J. Reed and G. Ceder, Electrochem. Solid-State Lett., 2002, 5(7), A145-A148.

29 J. B. Goodenough, Phys. Rev., 1960, 117(6), 1442-1451.

30 J. Kanamori, J. Phys. Chem. Solids, 1959, 10(2-3), 87-98.

$31 \mathrm{~J}$. B. Goodenough, Magnetism and the Chemical Bond, INTERSCIENCE (WILEY), 1963.

32 Y. Kumagai, A. Seko, F. Oba and I. Tanaka, Phys. Rev. B: Condens. Matter Mater. Phys., 2012, 85(1), 012401.

33 L. Croguennec, Y. Shao-Horn, A. Gloter, C. Colliex, M. Guilmard, F. Fauth and C. Delmas, Chem. Mater., 2009, 21(6), 1051-1059.

34 X. Xu, K. Takada, K. Watanabe, I. Sakaguchi, K. Akatsuka, B. T. Hang, T. Ohnishi and T. Sasaki, Chem. Mater., 2011, 23(17), 3798-3804.

35 R. F. W. Bader, Atoms in Molecules: A Quantum Theory, Oxford University Press, 1990.

36 W. Tang, E. Sanville and G. Henkelman, J. Phys.: Condens. Matter, 2009, 21, 084204.
37 K. Tatsumi, Y. Sasano, S. Muto, T. Yoshida, T. Sasaki, K. Horibuchi, Y. Takeuchi and Y. Ukyo, Phys. Rev. B: Condens. Matter Mater. Phys., 2008, 78(4), 045108.

38 J. B. Goodenough and Y. Kim, Chem. Mater., 2009, 22(3), 587-603.

39 J. R. Dahn, E. W. Fuller, M. Obrovac and U. von Sacken, Solid State Ionics, 1994, 69(3-4), 265-270.

40 H. Konishi, T. Yuasa and M. Yoshikawa, J. Power Sources, 2011, 196(16), 6884-6888.

41 Y. Furushima, C. Yanagisawa, T. Nakagawa, Y. Aoki and N. Muraki, J. Power Sources, 2011, 196(4), 2260-2263.

42 J. Suntivich, K. J. May, H. A. Gasteiger, J. B. Goodenough and Y. Shao-Horn, Science, 2011, 334(6061), 1383-1385.

43 T. A. Arunkumar, E. Alvarez and A. Manthiram, J. Mater. Chem., 2008, 18(2), 190-198.

44 A. D'Epifanio, F. Croce, F. Ronci, V. Rossi Albertini, E. Traversa and B. Scrosati, Chem. Mater., 2004, 16(18), 3559-3564.

45 H. Kondo, Y. Takeuchi, T. Sasaki, S. Kawauchi, Y. Itou, O. Hiruta, C. Okuda, M. Yonemura, T. Kamiyama and Y. Ukyo, J. Power Sources, 2007, 174(2), 1131-1136.

46 Z. Q. Deng and A. Manthiram, J. Phys. Chem. C, 2011, 115(14), 7097-7103. 